\title{
ISOLASI DAN IDENTIFIKASI BAKTERI SHIMBION SPONS PENGHASIL ENZIM AMILASE ASAL PANTAI MELAWAI BALIKPAPAN
}

\author{
Isolation and Identifications Bacterium Symbionts of Sponge as Producer \\ Enzyme Amylase From Melawai Beach of Balikpapan
}

\author{
Ismail Marzuki ${ }^{1}$; Alfian Noor ${ }^{2}$, Nursiah La Nafie ${ }^{2}$, M. Natsir Djide \\ E-mail: ismailmz3773@gmail.com \\ ${ }^{1}$ Postgraduate of Chemistry University of Hasanuddin, Makassar \\ ${ }^{2}$ Departement Of Chemistry, Faculty of Sciances, University of Hasanuddin, Makassar \\ ${ }^{2}$ Departement Of Fharmacy, Faculty of Fharmacy, University of Hasanuddin, Makassar
}

\begin{abstract}
Has been conducted research about isolation and identification bacterium symbionts sponge as producer enzyme amylase from Melawai Beach of Balikpapan. Targeting know is sponge type, symbionts bacterium group and test ability of sponge symbionts bacterium as amylase enzyme producer. Research expected to give information about existence of sponge and micro symbioning it's from Melawai Beach. Research executed in four phase namely analysis sponge morphology, macroscopic analysis of isolate, microscopic analysis through coloration of bacterium symbionts, and test ability of symbion bacterium in yielding amylase enzyme. Result of morphology analysis is Callyspongia sp species enter in Callyspongiidae of family relatives, while perceived by microscopic and macroscopic perception of symbion bacterium in form of small bar, ellipse, surfaceflatten, colony disseminate, ruddle, fastening safranin colour designate the bacterium is negative gram. Perception of activity amylase enzyme at MA medium show colony have amylase activity marked with formed it's of transparent zone at MA media colony if dropped by iodium condensation. Activity of amylase very high happened it thinning 10-2 marked with the existence of formed by zone of transparent very wide of around colony. Result of research concluded that $t$ sponge is Callyspongia sp species, symbionts bacterium group is negative gram and bacterium represent producer of amylase enzyme.
\end{abstract}

Keyword: sponge, micro symbionts, negative gram, amylase enzyme

\section{LATAR BELAKANG}

Lingkungan laut dalam kehidupan manusia sangat vital, bukan hanya sebagai sarana transportasi, lebih dari itu laut merupakan tempat hidup berbagai macam biota dan dibutuhkan untuk menjamin kelangsungan hidup. Sumber daya laut merupakan sumber daya hayati yang sangat potensial untuk dikembangankan dan dikelola secara maksimal.

Mikroorganisme dalam laut merupakan salah satu sumber daya yang memiliki potensi sebagai sumber senyawa bioaktif. Bakteri laut yang miskin nutrisi, banyak dijumpai membentuk mekanisme hidup dengan cara berasosiasi dengan berbagai organisme laut lainnya, seperti spons dan karang. Spons merupakan biota laut yang tersebar pada perairan pantai yang dangkal hingga perairan yang dalam.

Pantai Melawai Balikpapan cukup menarik dan terkenal sebagai salah satu destinasi wisata dan kuliner yang dikunjungi banyak orang, terletak disepanjang jalan Sudirman sebagai salah satu jalan protokol dan tidak jauh dari pusat Kota Balikpapan. Pantai Melawai yang banyak dikunjungi bukan hanya sekedar melihat terbenamnya matahari di sore hari tetapi juga sebagai sarana untuk menikmati 2 pulau di pantai tersebut yakni Pulau Kembar Tukung, (Jayardana, 2006).

Pantai Melawai juga merupakan pantai pasang surut dan tempat berlabunya kapal-kapal nelayan serta tempat memanjakan mata dengan melihat lalulintas kapal tanker, kapal barang dan kapal Pelni yang melintas, keadaan ini terjadi setiap hari, yang berpotensi memberi kontribusi peningkatan volume tumpahan minyak bumi, (Marzuki, 2014).

Informasi tentang adanya kehidupan spons pada Pantai Melawai tidak pernah terpublikasi, bahkan data Dinas Kelautan dan Perikanan Kota Balikpapan tidak memiliki data tentang adanya spons pada pantai tersebut. Hal ini cukup beralasan mengingat pada pantai tersebut hanya dikenal sebagai pantai tujuan wisata yang tercemar dengan limbah minyak bumi akibat keberadaan Kilang Minyak Balikpapan yang telah beroperasi sejak 
1973, sekaligus sekitar pantai tersebut terdapat Pelabuhan Semayang yang juga berkontribusi dalam peningkatan tingkat pencemaran. Namun faktanya berdasarkan observasi yang dilakukan pada Nopember dan Desember 2013 lalu, setidaknya ditemukan adanya spons yang hidup di Pantai Melawai tersebut, (Marzuki, 2014).

Temuan keberadaan spons pada Pantai Melawai Balikpapan menjadi informasi baru sekaligus sebagai alasan utama untuk melakukan penelitian awal tentang isolasi dan identifikasi bakteri penghasil enzim amilase yang bersimbiosis dengan salah satu jenis spons yang ada pada Pantai Melawai tersebut.

\section{TEORI}

Spons laut merupakan inang untuk bermacammacam mikroba seperti bakteri. Hal ini disebabkan spons dapat melindungi mikroba dari predator dengan cara menghasilkan senyawa kimia. Senyawa kimia yang dihasilkan spons akan menginduksi mikroba yang hidup di dalam spons untuk menghasilkan metabolit sekunder spesifik. Metabolit sekunder spesifik terekspresi sebagai bentuk respon mikroba terhadap kondisi lingkungan, dan memiliki berbagai aktivitas biologis seperti antimikroba, (Nofiani, 2009).

Penelitian terhadap organisme yang ada di lautan khususnya dalam kaitan dengan pencarian senyawa bioaktif dan enzim-enzim penting masih dalam tahap permulaan. Telah diketahui bahwa laut menyimpan kekayaan alam dan manfaat yang sangat besar. Salah satu kekayaan alam laut yang cukup banyak terdapat di perairan Indonesia, seperti di perairan Jawa, Sumatera, Sulawesi, Papua, Kalimantan dan lainnya, adalah jenis spons. Spons merupakan salah satu organisme hidup yang sudah ada sejak 600 juta tahun yang lalu. Spons dapat berasosiasi dengan sejumlah besar mikroorganisme berbeda meliputi Cyanobacteria, bakteri heterotrofik, alga uniseluler dan zoochlorellae, (Kuniawan. A., 2012).

Penelitian awal tentang isolasi dan karakterisasi suatu strain Bacillus baru yang berasosiasi dengan spons Mediterranean yaitu Aplysina aerophoba yang menghasilkan enzim penting seperti lipase dan esterase (Brusca dan Brusea, 1999). Spons merupakan salah satu komponen biota penyusun terumbu karang yang mempunyai potensi bioaktif yang belum banyak dimanfaatkan. Hewan laut ini mengandung senyawa aktif yang persentase keaktifannya lebih besar dibandingkan dengan senyawa-senyawa yang dihasilkan oleh tumbuhan darat, (Astuti, P., 2003).
Spons atau porifera termasuk hewan multi sel yang mana fungsi jaringan dan organnya masih sangat sederhana. Hewan ini hidupnya menetap pada suatu habitat pasir, batu-batuan atau juga pada karang-karang mati di dalam laut, (Amir dan Budianto, 1996). Spons merupakan biota multiseluler primitif yang bersifat filter feeder yang mampu menyaring air dan bahan-bahan lain di sekelilingnya melalui pori-pori (ostia) kemudian dialirkan ke seluruh bagian tubuhnya melalui saluran (channel) dan dikeluarkan melalui poripori yang terbuka (ostula), (Meutia, 2011).

Spons adalah hewan primitif, fungsi jaringan dan organnya masih sangat sederhana, sebagian besar hidup di laut dan hanya beberapa jenis di air tawar. Hewan ini mempunyai banyak pori-pori dan saluran-saluran. Untuk mencari makan, hewan ini aktif mengisap dan menyaring air yang melalui seluruh permukaan tubuhnya. Hewan ini termasuk metazoa multiseluler yang tergolong ke dalam filum Porifera, dan terdiri dari 850 jenis, yang dapat dibagi menjadi tiga kelas besar, yaitu Calcarea, Demospongiae dan Hexactinellida, (Amir dan Budianto, 1996).

Spons adalah hewan berpori yang termasuk filterfeeder yaitu hewan yang memiliki cara makan dengan menyaring air laut yang mengandung makanan melalui pori-pori (ostium). Makanan porifera berupa mikroorganisme atau sisa organisme mati yang berada di kolom air. Selain sebagai makanan mikroorganisme juga dapat menjadi simbion dengan menggunakan tubuh spons sebagai inangnya, untuk tempat hidup dan perlindungan. Sedangkan mikroorganisme dapat memberikan kontribusi untuk pertahanan inangnya dengan eksresi antimikroba dan substansi bioaktif lainnya. Organisme laut yang sesil seperti spons diperkirakan sangat bergantung pada mekanisme pertahanan kimia untuk melawan hewan-hewan predator dan perlekatan dari mikroorganisme pathogen, (Abubakar, 2011).

Konsistensi tubuh spons pada umumnya elastic seperti busa karet tetapi ada beberapa jenis yang keras dan agak rapuh. Tubuh spons ini diperkokoh oleh suatu kerangka spikula yang mengandung kalsium karbonat atau silica dan juga didukung oleh kerangka serat-serat keratin atau sponging, (Amir dan Budianto, 1996).

Sejumlah spesies spons yang hidup di perairan Spermonde, Sulawesi Selatan, kelimpahan kapang dan bakteri yang bersimbiosis cukup bervariasi pada spons. Kelimpahan jenis bakteri yang diisolasi dari spons pada umumnya didominasi oleh bakteri Aeromonas, Flavobacterium, Vibrio sp, 
Pseudomonas sp, Acinobacter dan Bacillus sp., (Brusca GJ. 1999). Pemeriksaan secara acak terhadap berbagai koloni dan pengamatan mikroskopis langsung menunjukkan bahwa 95\% bakteri laut bersifat Gram negatif. Bakteri laut sebagian besar bergerak secara aktif. Antara $75-85 \%$ sediaan murni yang diamati memiliki flagela. Diperkirakan kemampuan bergerak ini sebagai hasil adaptasi kehidupan perairan. Bakteri laut 70\% mengandung pigmen dan mempunyai toleransi yang besar terhadap suhu tinggi, (Pelczar dan Chan, 1986).

Bakteri laut mempunyai kemampuan mencerna hampir semua senyawa organik dan sebagian besar senyawa anorganik akan mengalami perubahan akibat kegiatan bakteri laut. Secara umum bakteri laut lebih kuat dalam hal mencerna protein dari pada karbohidrat. Perlu diketahui pula bakteri laut sangat peka terhadap turun atau naiknya salinitas larutan. Kebutuhan akan salinitas menunjukkan bahwa bakteri dari lingkungan berbeda memiliki toleransi garam dan kemampuan aklimasi tekanan osmosis yang berbeda pula. Sebagian besar bakteri yang mungkin diperkirakan kontaminan merupakan bakteri laut, (Sidharta, 2000).

Bakteri mampu berinteraksi dengan berbagai organisme laut, sehingga tidak ada satupun organisme laut yang bebas dari interaksi dengan bakteri. Salah satu bentuk interaksi bakteri ialah interaksi hubungan trofik yaitu interaksi bakteri baik yang hidup bebas maupun yang berada dalam partikel merupakan sumber makanan organisme laut mulai dari ciliata, spons, coelenterata hingga polychaeta, molusca, crustacea, holothurian dan tunicata. Mikroorganisme laut, seperti halnya makhluk hidup lainnya, sangat dipengaruhi oleh faktor-faktor abiotik (fisik dan kimia) lingkungan sekitarnya, Romimohtarto, 1999).

Faktor yang mempengaruhi keberadaan suatu mikroba, yaitu:

\section{Suhu}

Suhu air laut berkisar antara $2^{\circ} \mathrm{C}$ hingga $45^{\circ} \mathrm{C}$, yakni mulai dari suhu air laut daerah kutub sampai air laut di daerah tropis (perairan dangkal). Semua proses pertumbuhan bakteri bergantung pada reaksi kimiawi yaitu laju reaksi yang dipengaruhi oleh suhu, (Sidharta, 2000).

\section{Derajat Keasaman ( $p H)$}

Sebagian besar bakteri memiliki nilai $\mathrm{pH}$ minimum dan maksimum antara 4 dan 9 dalam pertumbuhannya. Pada umumnya $\mathrm{pH}$ optimum pertumbuhan bakteri terletak antara 6,5 dan 7,5. Namun, beberapa spesies dapat tumbuh dalam keadaan asam atau basa, (Pelczar dan Chan, 1986).

\section{Keberadaan Oksigen}

Kebutuhan oksigen pada bakteri tertentu mencerminkan mekanisme yang digunakan untuk memenuhi kebutuhan energinya. Berdasarkan kebutuhan oksigen tersebut, bakteri dapat dipisahkan menjadi anaerob, bakteri yang tidak perlu oksigen dalam metabolismenya di mana donor elektron diperoleh dengan memanfaatkan sumber lain selain oksigen dan aerob obligat, anaerob obligat, bakteri yang tidak dapat menyesuaikan diri dengan kedua situasi.

\section{Tekanan Osmosis}

Bakteri memiliki dinding sel yang kaku yang dapat menahan perubahan tekanan osmotik, sehingga biasanya tidak menunjukkan perubahan bentuk ataupun ukuran yang menyolok bila terjadi plasmolisis atau plasmoptisis.

\section{Faktor Nutrisi}

Kebutuhan nutrisi bagi mikroba terdiri dari substrat (sumber energi dan karbon) untuk pembentukan sel baru dan elemen anorganik (nutrien) serta faktor pertumbuhan (nutrien organik), (Shuler dan Kargi, 1992).

Nutrien (elemen anorganik) yang terutama (macro nutrient) yang dibutuhkan mikroorganisme adalah $\mathrm{N}, \mathrm{S}, \mathrm{P}, \mathrm{K}, \mathrm{Mg}, \mathrm{Ca}, \mathrm{Fe}, \mathrm{Na}$ dan CI. Sedangkan nutrien lain yang juga dibutuhkan dalam jumlah relatif tidak terlalu besar (micro nutrient) termasuk $\mathrm{Zn}, \mathrm{Mn}, \mathrm{Mo}, \mathrm{Se}, \mathrm{Co}, \mathrm{Cu}$ dan Ni. Mikroorganisme juga membutuhkan nutrien organik, yang lebih dikenal dengan faktor pertumbuhan. Faktor pertumbuhan adalah senyawa yang dibutuhkan mikroorganisme sebagai unsur pokok materi organik sel yang tidak dapat dibentuk dari sumber karbon lain, (Shuler dan Kargi, 1992, Fusetani, 1997).

Amilase merupakan enzim ekstraselular yang menghidrolisis pati dan menghasilkan produk dengan berat molekul yang lebih rendah. Dalam industri pangan, amilase banyak digunakan untuk produksi sirup dan proses pembuatan roti, (Kobayashi, 1993). Genus Bacillus menghasilkan $\alpha$-amilase yang mengubah pati menjadi dextrin maupun enzim yang mengubah pati menjadi gulagula yang lebih sederhana. Amilase dari Bacillus subtilis mempunyai aktivitas optimum pada kisaran $\mathrm{pH}$ 5-7. Enzim ini bersifat sebagai endoamilase yaitu enzim yang memecah pati secara acak dari tengah atau dari bagian dalam molekul, (Suhartono, 1989).

Isolasi bakteri pada spons penghasil enzim protoase ditemukan bahwa bakteri yang 
bersimbion dengan spons mampu menghasilkan enzim penting yaitu protoase. Adanya aktivitas protoase ditandai dengan terbentuknya zona bening di sekitar koloni. Dari hasil penelitian ini dapat diketahui bahwa dari 136 isolat yang berhasil diisolasi, sebanyak 36 isolat mampu menghasilkan aktivitas protoase baik dari permukaan maupun endofit spons, (Meutia, 2011).

Enzim yang diisolasi dari mikroorganisme dapat diaplikasikan pada berbagai macam industri. Misalnya enzim protease yang diisolasi dari Bacillus licheniformis, digunakan pada berbagai macam detergen sebagai bahan pembersih. Protease merusak dan melarutkan protein yang mengotori pakaian. Enzim yang dihasilkan untuk proses-proses industri meliputi protease, amilase, glukosa isomerase, glukosa oksidase, renin, pektinase dan lipase. Empat macam enzim yang secara luas diproduksi oleh mikroorganisme adalah protease, glukamilase, $\alpha$-amilase, dan glukosa isomerase, (Muniarsih, 1999).

Amilase digunakan dalam detergen dan dalam industri pembuatan bir. Ada beberapa tipe amilase, termasuk $\alpha$-amilase yang digunakan untuk mengubah pati menjadi oligosakarida dan maltose, $\beta$-amilase yang digunakan untuk mengubah pati menjadi maltose dan dekstrin, serta glukamilase yang mengubah pati menjadi glukosa. Ketiga enzim di atas digunakan untuk memproduksi sirup dan dekstrosa dari pati. Produksi amilase menggunakan fungi Aspergillus sp. Aspergillus oryzae digunakan untuk memproduksi amylase dari gandum pada kultur stasioner. Bacillus subtilis dan Bacillus diastaticus digunakan untuk memproduksi amilase bakteri, (Taylor, 2007).

\section{METODE PENELITIAN}

\section{Alat dan Bahan}

Alat yang digunakan adalahAutoklaf, Batang pengaduk, Cawan petri, Cool box, Erlenmeyer, Gelas ukur, Gelas kimia, Gunting, Inkubator, Laminary air flow, Mikropipet, Mortar, Ose bulat, Oven, Pinset, Pipet, Rak tabung, Sendok tanduk, Spoit, Tabung reaksi dan Timbangan analitik, Deck glass, Erlenmeyer, Handskun, Lampu spiritus, Lap kasar/ halus, Lumpang, Kertas indikator $\mathrm{pH}$, koloni counter, Korek api, Masker, Mikroskop, Objek glass, Penangas air, Pinset, Pipet tetes, Rak tabung, Sendok tanduk, Spoit, Stamper, Timbangan, Tabung reaksi, Termometer

Bahan yang digunakan adalah air laut steril, Aluminium foil, Amilum 1\%, Aquadest, Kapas, Kertas label, Larutan Iodium, Medium Merine Agar (MA), Tissue, air suling, alkohol $96 \%$,
Bakteri Shimbion, Spons, Pewarna kristal violet, Pewarna Larutan Lugol, Pewarna Metylen blue (MB), Pewarna Safranin.

\section{Waktu dan Tempat Penelitian}

Penelitian dilaksanakan pada bulan Maret - Mei 2014, di laboratorium Mikrobiologi Farmasi Fakultas Farmasi Universitas Indonesia Timur.

\section{Prosedur Analisis}

\section{Isolasi bakteri}

Sampel spons dicuci kemudian dipotong-potong kecil dan ditimbang 1 gram kemudian digerus menggunakan lumpang. Setelah halus dimasukkan ke dalam gelas kimia kemudian dilarutkan dalam 9 $\mathrm{ml}$ air laut steril sebagai larutan stock. Dilakukan pengenceran $10^{-1}$ sampai $10^{-6}$. Tujuan pengenceran adalah supaya diperoleh isolat yang tidak begitu padat dan mewakili semua jenis bakteri yang terdapat pada sampel. Bakteri yang terdapat pada sampel spons diinokulasi pada media MA dengan metode tuang. Diambil sebanyak $1 \mathrm{ml}$ untuk diinokulasi pada media MA dalam cawan petri \pm $15 \mathrm{ml}$ secara aseptik kemudian diinkubasi pada suhu $37^{\circ} \mathrm{C}$ di dalam inkubator selama 2X24 jam. Isolat bakteri menunjukkan ciri morfologi yang berbeda-beda seperti warna, bentuk koloni, dan jumlah koloni.

\section{Pemurnian Isolat Bakteri}

Dari kultur bakteri diambil 1 ose secara aseptic lalu diinokulasi dengan cara menggoreskan pada medium merine agar (MA), kemudian diinkubasi pada suhu $37^{\circ} \mathrm{C}$ selama $1 \mathrm{X} 24$ jam.

\section{Identifikasi dan pengamatan mikroskopik}

Proses identifikasi meliputi pewarnaan gram, dengan pengambilan biakan bakteri 1 ose pada objek glass yang sebelumnya telah dibebaslemahkan dengan alcohol $96 \%$, lalu ditetesi Kristal violet (Gram A) 1-3 tetes dibuat hapusan, diamkan kemudian dicuci menggunakan aquadest lalu dikeringkan, kemudian ditetesi larutan lugol (Gram B) 1-3 tetes, dibuat hapusan, diamkan, kemudian, dicuci dan dikeringkan, lalu ditetesi dengan alcohol asetat (Gram C) 1-3 tetes lalu dibuat hapusan, diamkan, dan dicuci menggunakan aquadest dan dikeringkan, kemudian ditetesi safranin (Gram D), dibuat hapusan kemudian didiamkan, lalu dicuci menggunakan aquadest dan dikeringkan, setelah itu diamati di bawah mikroskop dengan pembesaran 10X.

Bakteri Gram-negatif adalah bakteri yang tidak mempertahankan zat warna metil ungu pada metode pewarnaan Gram. Bakteri gram-positif 
akan mempertahankan zat warna metil ungu gelap setelah dicuci dengan alkohol, sementara bakteri gram-negatif tidak.

\section{Parameter yang dianalisa}

Pengambilan sampel dilakukan 1 hari. Parameter yang dianalisis adalah $\mathrm{pH}$, pengamatan dan pertumbuhan koloni, dan pewarnaan bakteri. Kemudian sampel diinokulasi dengan menggunakan metode agar tuang, diambil sebanyak $1 \mathrm{ml}$ untuk diinokulasi pada media MA dalam cawan petri sebanyak $15 \mathrm{ml}$ secara aseptik kemudian diinkubasi pada suhu $37^{\circ} \mathrm{C}$ selama $2 \times 24$ jam.

\section{Uji Amilase}

Aktivitas amilase diuji dengan menggunakan media Merine Agar (MA) yang ditambahkan amilum (1\%). Isolat kemudian digoreskan pada medium dengan metode gores. Lalu diinkubasi selama 1x24 jam. Jika pertumbuhannya bagus, diteteskan larutan Iodium pada permukaannya dan diamati zona bening di sekitar koloni biakan.

\section{HASIL}

\section{Hasil Analisis Morfologi sampel spons}

Hasil analisa morfologi keempat sampel spons disajikan dalam Tabel 1, berikut:

Tabel 1. Hasil Analisis Morfologi Spons Asal Pantai Melawai, Balikpapan

\begin{tabular}{|l|l|l|l|}
\hline SP & \multicolumn{1}{|c|}{ Spesies } & \multicolumn{1}{|c|}{ Famili } & \multicolumn{1}{|c|}{ Penemu } \\
\hline 1 & Callyspongia sp & $\begin{array}{l}\text { Callyspongi } \\
\text { idae }\end{array}$ & $\begin{array}{l}\text { Duchassaing \& } \\
\text { Michelotti, 1964 }\end{array}$ \\
\hline 2 & $\begin{array}{l}\text { Coelocarteria } \\
\text { singaporensis }\end{array}$ & Chalinidae & Carter, 1883 \\
\hline 3 & $\begin{array}{l}\text { Callyspongia } \\
\text { (Cladocalina) } \\
\text { vaginalis }\end{array}$ & $\begin{array}{l}\text { Callyspongi } \\
\text { idae }\end{array}$ & Lamarck, 1814 \\
\hline 4 & $\begin{array}{l}\text { Haliclona } \\
\text { (Haliclona) oculata }\end{array}$ & Chalinidae & Pallas, 1766 \\
\hline
\end{tabular}

Data Primer: telah diolah, September, 2014

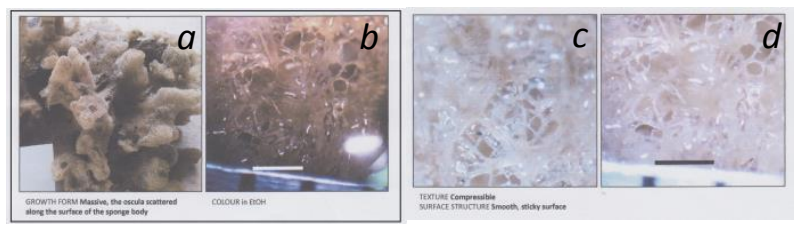

Gambar 1. Hasil analisis morfologi spons kode sampel 1, yakni: spesies Callyspongia sp., a) pertumbuhan membentuk massiva, oscula berserak sepanjang permukaan badan spons; b) hasil pewarnaan dengan EtOH; c) tekstur hasil kompres; d) struktur permukaan diperbesar

Dari keempat spesies spons yang diperoleh dari Pantai Melawai Balikpapan, setelah dianalisis morfologi diperoleh hasil ada 2 famili masing- masing terdiri atas 2 spesies, yakni family Callyspongiidae dengan spesies Callyspongia (Cladocalina) vaginalis dan Callyspongia sp serta family Chalinidae dengan spesies Haliclona (Haliclona) oculata dan Coelocarteria singaporensis.

Tabel 2. Hasil Isolasi Koloni Bakteri sampel spons

\begin{tabular}{|c|c|l|}
\hline Analisis & Pengenc. & \multicolumn{1}{|c|}{ Hasil Pengamatan } \\
\hline Makroskopik & $10^{-1}-10^{-6}$ & $\begin{array}{l}\text { Berbentuk bulat, permukaan } \\
\text { rata, koloni terpisah-pisah dan } \\
\text { menyebar ke seluruh } \\
\text { permukaan agar, berwarna } \\
\text { putih dan coklat }\end{array}$ \\
\hline
\end{tabular}

Keterangan: Dari hasil isolasi pada pengenceran $10^{-1}$ sampai $10^{-6}$ kesemuanya mempunyai bentuk koloni dan warna koloni yang sama.

Tabel 3. Hasil identifikasi Koloni Bakteri sampel spons

\begin{tabular}{|c|l|l|}
\hline Analisis & Pengenc. & \multicolumn{1}{|c|}{ Hasil Pengamatan } \\
\hline Mikroskopik & $10^{-1}$ & $\begin{array}{l}\text { Berbentuk batang dan spiral, } \\
\text { berwarna merah koloni kecil } \\
\text { dan besar }\end{array}$ \\
\cline { 2 - 3 } & $10^{-2}$ & $\begin{array}{l}\text { berbentuk batang terpisah- } \\
\text { pisah, berwarna merah }\end{array}$ \\
\cline { 2 - 3 } & $10^{-3}$ & $\begin{array}{l}\text { Berbentuk batang dan } \\
\text { berwarna merah }\end{array}$ \\
\cline { 2 - 3 } & $10^{-4}$ & $\begin{array}{l}\text { Berbentuk batang panjang, } \\
\text { berwarna merah }\end{array}$ \\
\cline { 2 - 3 } & $10^{-5}$ & $\begin{array}{l}\text { Berbentuk batang panjang, } \\
\text { dan berwarna merah }\end{array}$ \\
\cline { 2 - 3 } & $10^{-6}$ & $\begin{array}{l}\text { Berbentuk batang panjang } \\
\text { dan berwarna merah }\end{array}$ \\
\hline
\end{tabular}

Tabel 4. Hasil Pengujian Enzim Amilase Isolat Bakteri bersimbion dengan Spons

\begin{tabular}{|c|c|c|}
\hline \multirow{4}{*}{ Sampel } & $\begin{array}{c}\text { Konsentrasi } \\
\text { pengenceran }\end{array}$ & $\begin{array}{c}\text { Hasil tingkat } \\
\text { pengenceran }\end{array}$ \\
\hline \multirow{4}{*}{ Spons Laut } & $10^{-1}$ & ++ \\
\cline { 2 - 3 } & $10^{-2}$ & +++ \\
\cline { 2 - 3 } & $10^{-3}$ & ++ \\
\cline { 2 - 3 } & $10^{-4}$ & + \\
\cline { 2 - 3 } & $10^{-5}$ & + \\
\cline { 2 - 3 } & $10^{-6}$ & + \\
\hline
\end{tabular}

Keterangan:

$+\quad=$ zona bening sempit

$++=$ zona bening agak luas

$+++=$ zona bening sangat luas

\section{PEMBAHASAN}

Penelitian ini dilakukan dalam 4 tahap pengujian yakni; analisis morfologi spons, isolasi, identifikasi bakteri bershimbion spons dan uji enzim amilase dari bakteri shimbion spons. Sampel spons diambil dari Pantai Melawai Balikpapan, 
Kalimantan Timur pada kedalaman 2 meter, $\mathrm{pH} 7$ dan suhu pada saat pengambilan yaitu $29^{\circ} \mathrm{C}$. Sampel yang telah diambil kemudian dimasukkan ke dalam ice box. Dari hasil identifikasi spons yang diambil dari Pantai Melawai Kalimantan Timur diperoleh spesies jenis Callyspongia sp famili Callyspongiidae. Sampel spons digerus dan diencerkan dengan air laut steril hingga tingkat pengenceran $10^{-6}$, pengenceran ini dimaksudkan untuk meminimalkan jumlah mikroorganisme yang terdapat pada sampel sehingga memudahkan dalam pengamatan. Kemudian setiap konsentrasi pengenceran diambil $1 \mathrm{ml}$ dan dituang ke dalam cawan petri yang telah berisi medium MA (Marine Agar) yang merupakan medium spesifik untuk pertumbuhan bakteri yang berasal dari laut, setelah itu dimasukkan ke dalam inkubator selama 2 X24 jam pada suhu $37^{\circ} \mathrm{C}$, setelah diinkubasi pada suhu $37^{\circ} \mathrm{C}$ dilakukan pengamatan terhadap koloni yang tumbuh.

Dari hasil pengamatan diperoleh isolat selanjutnya dilakukan identifikasi yang merupakan pengamatan secara mikroskopik terhadap isolat yang diperoleh dari pengenceran tersebut dengan melakukan pengecatan gram.

Pengujian makroskopik dilakukan dengan melihat pertumbuhan koloni isolat tersebut. Pada permukaan medium terlihat bahwa koloni berwarna putih dan coklat, menyebar ke seluruh permukaan agar, berbentuk bulat serta koloninya terpisah-pisah.

Koloni biakan mikroba tersebut selanjutnya dimurnikan dengan cara digores pada medium Marine Agar miring MA yang sebagai medium spesifik. Teknik biakan murni yang digunakan adalah metode penggoresan agar sinambung.

Pemurnian isolat bakteri bertujuan untuk memisahkan hasil inokulasi yang terdiri dari banyak koloni bakteri yang berlainan jenis sehingga didapat koloni bakteri murni pada setiap biakan bakteri. Koloni bakteri yang diambil untuk dimurnikan adalah koloni yang dominan. Pemurnian dengan menggunakan metode cawan gores, (Waluyo L, 2008).

Selanjutnya identifikasi dilakukan dengan pengujian mikroskopik dilakukan dengan pengecatan gram yang bertujuan untuk, pemberian cat A (Kristal Violet) pada bakteri gram positif akan diserap dan diikat pada bagian sel terluar. Pemberian cat B (Lugol) meningkatkan afinitas pengikatan zat warna oleh bakteri sehingga pengikatan zat warna menjadi lebih kuat. Setelah penambahan Lugol, zat warna akan lebih jelas terlihat dan zat warna lebih sulit dilarutkan, penambahan iodium menyebabkan terbentuknya persenyawaan kompleks kristal violet dan laktofenol. Tanpa penambahan laktofenol, zat warna kristal violet akan larut sewaktu penambahan alkohol sehingga bakteri gram positif tidak akan berwarna ungu. Pada pemberian cat $\mathrm{C}$ (alkohol 96\%), bakteri gram positif tetap berwarna ungu karena kompleks persenyawaan kristal violet dan laktofenol tetap terikat pada dinding sel. Pada penambahan cat D (safranin), tidak menyebabkan perubahan warna bakteri gram positif, karena persenyawaan kompleks kristal violet dan iodium tetap terikat pada dinding sel, (Irianto, 2006).

Setelah melewati proses pemberian cat A (kristal violet), cat B (lugol), cat C (alkohol 96\%), serta cat D (safranin) ternyata isolat termasuk ke dalam bakteri gram negatif yang ditunjukkan pada mikroskop untuk pengencenran sampai $10^{-6}$ yaitu semuanya adalah bakteri gram negative yang mempertahankan warna safranin (warna penutup). Hal ini disebabkan bakteri gram negative mempunyai kadar lipid dan protein yang tinggi, (Hartati, 2012).

Dari hasil identifikasi pada pengamatan di bawah mikroskop bentuk yang diperoleh yaitu berbentuk batang kecil dan panjang, dan warna yang diperoleh yaitu warna merah yang menandakan bakteri tersebut adalah gram negative yang mengikat zat warna $\mathrm{D}$ atau zat warna penutup yaitu safranin.

Pengamatan aktivitas enzim amilase pada medium Merine Agar menunjukkan bahwa semua koloni pada sampel menunjukkan adanya aktivitas amilase. Isolat yang menghasilkan enzim amilase menghasilkan zona bening pada agar di sekitar koloninya jika ditetesi dengan larutan iodium. Di mana aktivitas amilase sangat tinggi terjadi pada pengenceran $10^{-2}$ yang ditandai dengan adanya zona bening yang terbentuk sangat luas di sekitar koloni setelah penambahan larutan iodium. Hal tersebut menandakan bahwa amilum pada daerah tersebut telah terhidrolisis sempurna oleh enzim amilase. Sedangkan untuk pengenceran $10^{-4}, 10^{-5}$ dan pengenceran $10^{-6}$ zona bening setelah penambahan larutan iodium sedikit yang artinya daya ikat enzim amilase terhadap iodium juga kecil, hal ini terlihat pada medium yang masih berwarna biru kehitaman. Sedangkan untuk pengenceran $10^{-1}$ dan $10^{-3}$ aktivitas amilasenya cukup tinggi yang ditandai dengan adanya zona bening di sekitar koloni yang agak luas.

Adanya penambahan larutan iodium berfungsi untuk mengetahui kemampuan bakteri menggunakan pati. Degradasi yang terjadi pada 
pati diketahui dengan hilangnya material yang terwarnai oleh iodin. Kemampuan atau daya amilolitik suatu mikroba ditandainya dengan terbentuknya zona jernih dalam medium Merine Agar yang mengandung pati. Hal ini sesuai dengan literatur di mana setiap isolat murni yang dapat tumbuh diasumsikan dapat menggunakan media yang mengandung pati. Untuk memastikannya dilakukan uji iodin dengan cara meneteskan iodin pada permukaan agar yang berisi isolat, bila terdapat zona bening pada media mengindikasikan enzim amilase diproduksi oleh isolat sehingga di daerah tersebut amilum sudah dihidrolisis sedangkan media yang berwarna biru kehitaman menandakan pati di tempat itu belum terhidrolisis. Sebelum pengujian tiap isolat disiapkan stok kulturnya pada media miring, (Pelczar \& Chan, 1986).

\section{KESIMPULAN}

Dari sampel spons laut yang diambil dari Pantai Melawai Kalimantan Timur yang telah diamati berdasarkan pengamatan morfologi, pengamatan makroskopik, pengecatan dan pengamatan mikroskopik dan uji aktivitas enzim amilase diperoleh hasil jenis spons adalah spesies Callyspongia sp famili Callyspongiidae, bakteri shimbion adalah Kelompok bakteri gram negatif dan bakteri tersebut sebagai penghasil enzim amilase.

\section{REFERENSI}

Amir, I dan Budiyanto. 1996. Mengenal Spons Laut (Demospongiae) Secara Umum. Oseana, Volume XXI, Nomor 2, 1996: 15 31.

Anonim, 20111. Eksplorasi Spons (Porifera). (http://dhama dharma. Word press.com/ 2011/ 11/09/ eksplorasi-spons-porifera/, Diakses 25 April 2014).

Abubakar, H., A. T. Wahyudi, M. Yuhana. 2011. Skrining Bakteri yang Berasosiasi dengan Spons Jaspis sp. Sebagai Penghasil Senyawa Antimikroba. Ilmu Kelautan. Jakarta.

Astuti, P., 2003, Spons Invertebrata Laut Berpotensi sebagai Sumber Bahan Baku Obat Alam, vol 8 No.26 Oktober-Desember (Edisi khusus). Bagian Biologi-Farmasi, UGM, Yogyakarta.

Bergquist, PR (2001). "Porifera (Spons)". Encyclopedia of Life Sciences. John Wiley \& Sons, Ltd. doi: 10.1038/npg.els.0001582
Brusca RC, and Brusea GJ. 1999. Phylum Porifera the Sponges. AD. Sinauer (ed), Invertebrates (Sinnauer Press) PP.181-210. Sunderland, Mass.

Fusetani, N.,J Warabi, K. Nogata, Y., Nakao, Y \& Matsunaga, S. 1997. Koshikamide Al, a new Cytotoxic Linear Peptide Isolated from a Marine Sponge, Theonella sp. Tetrahedron letters 40, 4687-4690.

Hartati, 2012. Dasar-dasar Mikrobiologi Kesehatan. Nuha Medika. Surakarta

Huda. C. 2011. Penapisan Aktivitas dari Bakteri yang Berasosiasi dengan Karang Lunak Sarcophyton sp. Fakultas Matematika dan Ilmu Pengetahuan Alam Universitas Sriwijaya.

Irianto, K. 2016. Mikrobiologi Medis. Alfabeta. Bandung

Jasin, M., Zoologi Invertebrata Untuk Perguruan Tinggi, Cetakan Keempat, Penerbit Sinar Wijaya, Surabaya, 1992.

Jayardana Trigunawan, 2006. Penilaian Terpadu Dampak Tumpahan Minyak Di Perairan Balikpapan: Studi Kasus Tumpahan Sludge Oil Dari Kapal Mt. panos, Tesis UI.

Kobayashi J \& Ishibashi M. 1993. Bioactive metabolites of symbiotic marine microorganisms. Chem Rev 93.

Kuniawan. A., 2012. The Isolation and Identification of Petrofilic Bacteria From Total Petroleum Hydrocarbons (TPH) Residues Under $1 \% \quad(W / W)$ of Bioremediation Process Results, ITS-ECO Campus

Lee, Y.K., J.H., Lee, H.K., Lee, 2001. Microbial Symbiosis in Marine Sponges. Journal Microbial, 30: 254-264.

Marzuki, Ismail, 2014. Analysis of Heavy Metal sea Sediment from Melawai Beach of Balikpapan, East Kalimantan, Prosiding International Conference of the Indonesian Chemical Society, Unpatti, Ambon, 17-18 September 2014

Meutia Samira, et al., 2011. Morfologi dan Biomassa Sel Spons Aaptos aaptos dan Petrosia sp. Jurnal Ilmu dan Teknologi Kelutan Tropis, Vol. 3, No. 2, Hal. 153-161

Muniarsih. T., et. al., 2009. Biodegradasi Fenantren oleh Bakteri Laut Pseudomonas 
sp KalP3b22 Asal Kumai Kalimantan Tengah. Makara Sains Vol 13 (1): 77-80

Muniarsih T, dan Rachmaniar R. 1999. Isolasi Substansi Bioaktif Antimikroba dari Spons Asal Pulau Pari Kepulauan Seribu. Prosidings Seminar Bioteknologi Kelautan Indonesia I '98. Jakarta 14 - 15 Oktober 1998: 151 - 158. Lembaga Ilmu Pengetahuan Indonesia Jakarta, 1999.

Murni E, 2014. Pantai Melawai, Kota Balikpapan Kalimantan Timur. (http://wisata melayu.com $>$ Beranda $>$ Wisata Panta $\underline{1}$, diaskes 26 Maret 2014).

Nofiani. R, Nurbetty. S, Sapar. A. 2009. Aktifitas Antimikroba Ekstrak Metanol Bakteri Berasosiasi Spons Dari Pulau Lemukutan Kalimantan Barat. Universitas Tanjung Pura: Pontianak.

Nurhayati, T., et al., 2006. Karakterisasi awal inhibitor protease dari bakteri yang berasosiasi dengan spons asalPulau Panggang, Kepulauan Seribu, Jurnal Hayati 13(2):58-64

Pastra DA, dkk, 2011. Pemapisan Bakteri yang Bersimbiosis dengan Spons Jenis Aplysina sp Sebagai Penghasil Antibakteri dari Perairan Pulau Tegal Lampung

Pelczar, M. J., Chan, E. C. S. 1986. Dasar-Dasar Mikrobiologi. Jilid I. Terjemahan Ratna Siri Hadioetomo. UI Press, Jakarta.

Pratiwi, S. T. 2008. Mikrobiologi Farmasi. Erlangga Medical Series; Yogyakarta Pusat Kajian Sumberdaya Pesisir dan LautanInstitut Pertanian Bogor.2012. (http:/ /www.indomarine.or.id/english/detailnews. php?id=118\&page $=$ artikel, $\quad$ diaskes 26 Maret 2014)

Ramli. 2010. Distribusi dan Kepadatan Spons Pada Beberapa Pulau di Perairan Kota Makassar. Thesis. Fakultas Ilmu Kelautan dan Perikanan.UNHAS. Makassar

Romimohtarto dan K. Juwana S. 1999. Biologi Laut. Ilmu Pengetahuan Tentang Biota Laut. Pusat Penelitian dan Pengembangan Oseanologi-LIPI. Jakarta.

Shuler, ML, \& Kargi, F. 1992. Bioprocess Engineering. Prentice Hall. USA.

Sidharta, Boy Rahardjo. 2000. Pengantar Mikrobiologi kelautan. Universitas Atma Jaya Yogyakarta. Yogyakarta.

Suhardi, 2002. Evolusi Vertebrata. Universitas Indonesia. Jakarta

Suhartono MT. 1989. Enzim dan Bioteknologi. Dep. Pendidikan dan Kebudayaan Direktorat Jenderal Pendidikan Tinggi Antar Universitas Bioteknologi IPB.

Taylor, M.W., Radax, R., Steger, D., \& Wagner, M., 2007, Sponge-associated microorganisms: evolution, ecology, and biotecnological potential. Microbiol. Mol. Bio. Reviews, 2: 295- 347.

Waluyo L, 2008. Teknik Metode Dasar Mikrobiologi. Universitas Muham-madyah. Malang

Wilkinson CR. 1992. Symbiotic interactions between marine sponges and algae. In Algaeand symbioses: plants, animals, fungi, viruses, interactions explored, pp. 112-128. Edited by W. Reisser. Bristol: Biopress Ltd. 